Dialectologia 15 (2015), 69-85.

ISSN: 2013-2247

Received 7 April 2014.

Accepted 10 June 2014.

\title{
FORGING THIRD-WAVE DIALECTOLOGY
}

\author{
Kirk HAZEN \\ West Virginia University \\ Kirk.Hazen@mail.wvu.edu
}

Abstract

After 50 years of scholarship, variationist methods have been expanded to accomplish a wider diversity of goals, yet early approaches developed from $20^{\text {th }}$ century dialectology and served dialectological goals. After the 1990, the broader field of sociolinguistics began to shift its focus from the correlation of demographic categories with sociolinguistic variables at the level of the speech community to the explanation of social meaning as created by individuals' use of language variation patterns, designated as a shift to a third-wave of sociolinguistics. In this shift, there is less focus on dialects as geographically anchored entities, but there is also an opportunity to foster dialectology to account for individuals' patterns within dialects. This paper illustrates how the traditional dialectology methods can be used to establish "third-wave dialectology".

\section{Keywords}

dialectology, first-wave variation studies, third-wave variation studies, Appalachian English, sociolinguistics, language variation and change 


\section{FORJANDO LA TERCERA ÉPOCA DE LA DIALECTOLOGÍA}

Resumen

Después de cincuenta años de investigación, los métodos variacionistas se han ampliado hasta lograr una mayor diversidad de objetivos; incluso las primeras aproximaciones se desarrollaron des de la dialectología del siglo 20 y tuvieron objetivos dialectales. A partir de 1990, el campo más amplio de la sociolingüística comenzó a cambiar su enfoque desde la correlación de las categorías demográficas con variables sociolingüísticas a nivel de la comunidad de habla a la explicación del significado social como creado por el uso de los individuos de patrones de variación del lenguaje, designado como un cambio a una tercera época de la sociolingüística. En este cambio, se pone menos énfasis en los dialectos considerados entidades geográficamente ancladas, y más en fomentar la dialectología para dar cuenta de los patrones individuales dentro de dialectos. En este trabajo se muestra cómo los métodos tradicionales de la dialectología se pueden utilizar para situar "la tercera época de la dialectología".

\section{Palabras clave}

dialectología, primera época de los estudios sobre la variación, tercera época de los estudios sobre la variación, el inglés de los Apalaches, sociolingüística, variación lingüística y cambio

\section{Introduction: The concurrent approaches of first-wave and third-wave variationist analysis}

This paper focuses on the utility of combining first-wave and third-wave sociolinguistic variationist studies to achieve a "third-wave dialectology". When assessing any two different methodological paradigms, some preliminary points of focus need to be kept in mind as researchers consider combining first- and third-wave goals for their own projects.

The terms first-wave sociolinguistics and third-wave sociolinguistics come from Eckert's analysis of sociolinguistics development (Eckert 2014 and www.stanford. edu/ eckert/thirdwave.html). First-wave sociolinguistic work was a branch of linguistics with close methodological connections to dialectology, predominantly correlating language variation with demographic social descriptors. Studies such as Labov (1966 [2006]) and Wolfram (1969) are foundational examples of such combinations of dialectology and linguistics. Second-wave sociolinguistics began to ask questions related 
to the fields of anthropology and social psychology. For example, Milroy \& Margrain (1980) expanded the search for language change by developing methods of social network analysis in data of Belfast neighborhoods. Third-wave sociolinguistics focuses on style and construction of identity. Researchers in this approach assume that social categories-such as gender, sexual orientation, and ethnicity-are co-constructed by participants: In the speech of Michigan teenagers, Eckert (2000) examined the social meaning of vowel variation rather than just examining vowel variation and its social correlates.

As a preliminary point, we need to keep in focus the object of study. Does the research project answer questions about the individual in society or about language? Certainly, sociolinguistic projects can do both, but usually one is more of a central focus than the other. Linguistics is the science of language, but social constructionist and identity approaches are studies of humanities, anthropology, sociology, and social psychology. These approaches form the basis of third-wave sociolinguistics (Eckert 2000, 2008). From the first-wave variationist front, one of Labov's innovations was that he assumed proper study of linguistic and language variation could not be done without social information or without individuals who propagate changes, but Labovian variationist analysis is still a linguistic enterprise (Hazen, 2011b).

Second, we need to consider the locus of the object under study. In the Labovian tradition, the speech community, at the level of language termed dialect, is where the structure and patterns of variation play out. As Labov has said, in terms of language variation and change, there are no individuals since they all get their patterns from the community grammar (Gordon 2006: 341). In studies of social meaning, individuals are integrated into the social landscape. This landscape is unspecified as to where the language variation in question is taking place, but usually the theoretical work deals with society outside the mind of any one individual. Although not a direct argument for this paper, I would suggest that sociolinguists of all stripes consider the mental implications of their theories and connect the search for social meaning more directly with models of the mental grammar.

Third, we should predetermine if the methodology of a study is qualitative only or quantitative also. The path to quantitative study is through qualitative analysis, yet the 
qualitative analysis is a worthy goal unto itself. Labovian tradition has been quantitative, and its success results from the methodological power of quantitative evidence. The subject matter, social or linguistic, does not restrict which type of method to adopt, but the qualitative approach does restrict the kinds of claims which can be made.

In this paper, I quickly touch upon the history of variationist work with an eye to dialectology and sociolinguistics, including the modern third-wave variationist approach. I next highlight a 12-year study of English in Appalachia and reveal the limits of what the dialectological demographic grouping of first-wave methods can reveal. Yet within those limits, I show how first-wave results should lead to third-wave studies. I further discuss how a third-wave focus on the linguistics of language variation provides the means to properly assess social meaning. Lastly, I provide a detailed example of how first-wave methods can open up rich topics for third-wave analysis, with the end goal of building third-wave dialectology.

\section{A historical glance at variationist work with an eye to the modern}

Although a wide variety of arguments have been made in variationist linguistics, they generally adhere to some basic tenets. Jones and Tagliamonte enumerate these "lines of evidence: (1) Which of the following factors is statistically significant? (2) What is the relative contribution of the linguistic features selected? Is it strong or weak? (3) What is the constraint ranking of the categories within each factor? (4) Finally, does this order reflect the direction reported in the literature?" (2004: 110). This approach incorporates the essence of variationist language analysis: quantitative empirical elucidation contributing towards a descriptive and explanatory analysis. Most often social and linguistic factors are considered, in line with variationists' sociolinguistic roots, but the social factors have not traditionally been the object of study.

As Chambers (2002: 6) perceptively remarks, "The relationship between traditional dialectology and sociolinguistics is oblique rather than direct, but both in the broadest sense are dialectologies (studies of language variation). In terms of intellectual history it is plausible to view sociolinguistics as a refocusing of traditional dialectology". 
Dialectologia 15 (2015), 69-85.

ISSN: 2013-2247

From dialectology, the conceptual field was fertile for the growth of the linguistic variable and its methodology; yet with variationist methodology, the focus of study became detached from strictly regional dialects. At times variationist sociolinguistics has focused on social dialects, but more rarely on the social meaning of language variation patterns created by individual speakers.

Early variationist work was a branch of linguistics with close methodological connections to earlier dialectology. The initial variationist projects were tied to sociology projects and took up demographic social descriptors. The focus was on larger sociological categories and the speech community in order to model how languages change; this focus was not on meaning in the reference sense, because meaning had been largely abandoned by phonologists and Chomskyan syntacticians. Over the last few decades, researchers have asked what language variation patterns mean for individuals, and the answers from percentages and linear-regressions of demographic categories and phonological conditioning environments did not have much to say. Some scholars turned to different kinds of sociolinguistic research questions related to the fields of anthropology and social psychology. From those research questions and their related study, third-wave variationist analysis began. This does not mean that first-wave analysis disappeared. The two kinds of variationist analysis ask different research questions to find out different kinds of answers.

The bridge between quantitative variationist study and the examination of social meaning has been most successfully built by Eckert (2000). Whereas many previous and subsequent studies focus on a single variable to elicit social meaning out of a community, Eckert (2000: 213) argues:

While the individual variables available in a dialect may correlate with various aspects of social membership and practice, most of them take on interpretable social meaning only in the context of the broader linguistic styles to which they contribute, including both the inventory of variables and their use. When we view each variable in isolation, thinking of speakers as leading or lagging in the use of advanced variants, we miss the overall effect of speaker's choices. 
Social meaning from this perspective is a result of the creative process of style from all speakers and not a static entity attached to any one (or set of) variables (see also Coupland 2007, 2014).

In the third-wave approach, the question is how meaning, including identity, is composed and negotiated by individuals. In the dialectological, first-wave approach, the focus is on the dialect as separate from the holders of the dialect and on how language changes alter the reified object (the dialect). In the generative and perhaps diachronic approaches, the concern is the language and the linguistic factors which influence its operation (production or perception). All of these approaches to language study have used variationist methodology to advance their academic ends; however, their goals are not the same and the emphasis on variationist analysis is often different.

The third wave of variationist analysis focuses on how individuals construct social meaning. Moore (2011: 221) writes, “... sociolinguists in the third wave attempt to answer the question of how it is that a variable might come to mean 'upper-class New Yorker' or 'rebellious adolescent girl' ...this entails analyzing meaning at a level which is different from the social groups or categories considered in first- or second-wave research". Moore (2011: 220) contrasts that approach with first-wave sociolinguists who focus on "correlating broad demographic categories such as gender, class, ethnicity and age with language use in geographically delimited speech communities". Also different from third-wave approaches, the second-wave approach "...attempts to redefine the concept of 'social group' to account for more localised taxonomies" (Moore 2011: 220).

The third-wave draws from fields such as sociology, social psychology, and anthropology in order to analyze how individuals construct their persona/identity through the social meanings developed in the deployment of style. Moore (2011: 222) writes:

Meaning will shift and adapt dependent upon the wider style in which social and linguistic resources are used, and we will interpret identities based upon our understanding of the whole style. As Eckert has argued, to understand identity, then, we need to understand 'style'; this has been a major goal of the third wave of variationist sociolinguistics. 
This description of research changes the object of study from linguistic analysis of how language variation and change works to a social analysis of how sociolinguistic style and personal identities are created.

\section{The WVDP plan to incorporate first-wave results into third-wave studies}

The West Virginia Dialect Project (WVDP) began a 12-year project in 2007 to investigate the sociolinguistic qualities of English in Appalachia. The overall project comprises three stages:

1. A Sociolinguistic Baseline for English in Appalachia: NSF BCS-0743489

2. Phonetic Variation in Appalachia: NSF BCS-1120156

3. Community Studies of Social Change in Appalachia (2016)

The primary goal for the overall project is to conduct quantitative sociolinguistic analysis on English in West Virginia (WV) to determine its status, including its regional affiliations, its relative degree of vernacularity, its sociolinguistic divisions, the social meanings attached to its vernacular forms, and its current direction of change. I argue here that all of the first-wave goals can be used for a third-wave analysis of how Appalachians deploy their language to construct style and identity.

Stage 1 included analysis of ten sociolinguistic variables for a thorough study of English in Appalachia. From the research accomplished to date, it is clear that many of the traditional vernacular features of English in Appalachia are fading from West Virginia. For example, a-prefixing (e.g. She was a-fishing) has been a classic feature for decades, but WVDP results concur with work from the early 1970s that indicates the dialect feature is quickly fading from nonperformance usage (Hazen, Butcher \& King 2010). In contrast, the vernacular language variation patterns of alveolar -ING (e.g. walkin') and -t/-d deletion (e.g. bes' apple) remain a stable part of English in Appalachia (Hazen 2008, Hazen 2011a). For those dialect features that remain robustly variable, only some mark social boundaries. Increased rates of alveolar -ing correlate strongly 
with lowered social class and origins in the Southern half of WV, but $-t /-d$ deletion shows weak social marking.

Stage 2 involves phonetic analysis of consonants and vowels in order to enhance the description of the WV region provided in the Atlas of North American English. Differences in phonetic qualities of consonants and vowel systems do mark the dialect regions of WV, but increasingly these regional characteristics are being adopted as social markers of rural/nonrural. The Northern and Southern halves of WV generally have both the front-lax merger (e.g. pin $\sim$ pen) and the low-back merger (e.g. cot ${ }^{\sim}$ caught), but the Northern Panhandle has the cot ${ }^{\sim}$ caught merger only (Hazen 2005). Parts of the Southern region of West Virginia are distinct by participating in the Southern Shift (Fridland 2000; Labov 2001). The extent and progression of the Southern Vowel Shift is assessed in Stage 2: How complete is the shift in the socioculturally Southern parts of the state? Geographically, how far north does the Southern Vowel Shift stretch? In preparation for Stage 3, do rural areas demonstrate more advanced characteristics of the Southern Vowel Shift? In addition for Stage 2, several consonant variables will be analyzed and contrasted, including L-vocalization, WH/W merger, $\mathrm{H}$-lenition, and $\mathrm{S} Z \mathrm{Z}$ voicing contrasts. Some of these consonants are changing for speakers; for example L-vocalization is decreasing across apparent time. Others show innovative patterns: Numerous speakers have more voiceless Ws in words such as wet, witch, and wail than they do in the word-class of WHs, namely whet, which, and whale.

In Stage 3 of the project, the knowledge gained from the first two stages is applied in an analysis of changing WV communities. As the United States transitions away from rural communities towards ever-larger suburban communities (Ching \& Creed, 1997), the WV sociolinguistic landscape is changing, and along with it, English in Appalachia. The first two studies provide a view of demographic groups and dialectological regions. Stage 3 tracks how those linguistic features develop and change within the flow of local identities. Following Eckert (2000) and Hazen (2002), within a community, do regionally or demographically marked sociolinguistic features become reinterpreted for local identities? Two overlapping studies are planned: a comparison between a rural and suburban high school in the same county for both the Northern and Southern dialect region (four high schools total); a comparison between a rural small town and a 
suburban community for both the Northern and Southern dialect region. With a thorough knowledge of the diagnostic sociolinguistic variables garnered from the first two stages, changes to local sociolinguistic boundaries can be discovered and our knowledge of how people form their sociolinguistic identity can be enhanced.

Here, I discuss an exposition of findings on the demographic category of speaker's sex with five quantifiably analyzed variables drawn from Stage 1 of this project. A terminological note from Eckert's discussion above: The first stage of this project focused on variables rather than styles. Speakers use language variation to create styles, but variables and styles are quite different things. These five variables are shared with many other English-speaking communities:

(ING) (e.g. she was walkin')

Was leveling (e.g. We was out late)

Coronal Stop Deletion (e.g. nest -->nes')

Demonstrative them (e.g. How about them apples?)

Quotative like (e.g. She was like, "I'm not going.")

Each of these variables was correlated with social categories, and following firstwave methodology, those categories are mostly demographically based. These were primarily divided by sex, age, and region. The resulting West Virginia Corpus of English in Appalachia was constructed to balance out these three criteria and provide updated sociolinguistic information, as the data on English in West Virginia had not previously been updated since the early 1970s. Additionally, the social categories of social class, ethnicity, and education were also correlated for the variants under investigation.

For this project, the WVDP designated social class on the basis of occupation (or occupation of the parents, if the subject was a minor), housing conditions, selfdiscussion of high school cliques, and living conditions (whether they had to work while in high school, their hobbies, etc.). These designations were used in addition to a host of other factors, including the speakers' own perceptions of their social class standings, their extracurricular activity choices, and their explanations of their belongings. This study uses divisions of working class, a lower-middle class, and an upper-middle class.

Ethnicity was divided into self-identifying African American speakers and European American speakers. Educational experience was developed from former studies of local 
identity (Hazen 2002) and divided into two categories: those speakers with no postsecondary school experience and those with any educational experience after high school (even a single community college class). With this social division, the intent was to check for orientation to a larger community's norms and to see if the speaker's identity was directed away from their local community.

The social findings generally reinforce the legitimacy of using such broad categories as a first assessment of sociolinguistic practice: Each of them was found to be significant for some kind of social variation, even if the correlation was weak. But as they are general categories, they provide only the broadest outlines of answers, not the specific details of how speakers use the language variation patterns in question to make meaning. As we review the social findings of each variable, it is important to keep in mind that first-wave studies focus on the speech-community level of language variation.

For the social division of sex, a few results appeared which would not have been predicted by previous literature. For example, with the [in] variant of (ING), it has been found in many communities that males use it more often; the vernacular status of the variant has most often been cited as the motivation for this difference. Within WVCEA, the females had a rate of $53 \%$ [in] $(\mathrm{N}=3,299)$ and the males had a rate of $51 \%(\mathrm{~N}=3,683)$ (Hazen 2008). For a third-wave study, this slight yet significant difference in the unexpected direction might be a good area to investigate for the construction of personal identity (e.g. following Campbell-Kibler, 2008). For the other four variables, the expected results occurred for the sex divisions. Both leveled was and demonstrative them are stigmatized within West Virginia, although demonstrative them is much more stigmatized (Hazen, Hamilton \& Vacovsky 2011). Females have lower rates of both stigmatized variants. For demonstrative them, females only have $9 \%$ them $(N=253)$ where as males have $18 \%(\mathrm{~N}=281)$. For leveled was, the feature was common throughout the 20th century and remained at high rates in the 1970s (Wolfram \& Christian, 1975), but rates declined rapidly after this point. A divide by sex of the speaker was not present in the oldest speakers: The oldest females had a rate of $56 \%$ leveled was $(\mathrm{N}=282)$ while the males had a rate of $51 \%(\mathrm{~N}=224)$. For the youngest speakers (born after 1980), a striking difference appears: Females only had a rate of $2 \%$ $(\mathrm{N}=262)$ while the males had a rate of $19 \%(\mathrm{~N}=120)$. 
With the coronal stop deletion (also known as -t/-d deletion), social differences were not that influential, as has been found in most other communities (Hazen 2011a). Yet a significant difference remained for sex, with females having a higher rate of deletion, with a rate of $63 \%(N=4,577)$, than males did at $57 \%(N=4,977)$. It is hard to generalize to the entire population from such a sample, but at least within the sample, it seems that the females have higher vernacular rates than the literature would predict.

One of the widest divides by sex is for quotatives. For the oldest speakers, quotative be like was not an available token, but the middle-aged and youngest speakers picked it up rapidly after it spread from the west coast at the start of the 1980s. For middle-aged speakers, the divide between females and males is substantial, with females having be like $54 \%$ of the time quotatives are used $(\mathrm{N}=240)$ and males only having a rate of $30 \%(\mathrm{~N}=209)$. The youngest speakers widen out that divide, with females having $73 \%$ be like ( $N=623)$ and males having $45 \%(N=222)$.

This kind of demographic category comparison can be done across the available spectrum of categories for multiple variables, and general insights about which category of speakers produce more or less of a variant can be determined from the data. These first-wave examinations provide suggestions for creating and conducting third-wave studies in variationist linguistics. Certainly, these first-wave results do not answer global questions (e.g. How do people construct their gender through language use?). These results only give the barest hint at how people in Appalachia construct their gendered identities through language variation, but they do provide details about what kinds of socially significant language variation patterns are available and how linguistic constraints operate on those patterns. To answer the third-wave questions, the community-level analysis must be carefully paired with detailed quantitative description of how speakers use styled constellations of language variation patterns in the construction of social meaning.

One of the best points of connection for first-wave studies to enhance third-wave research projects is at the boundaries of vernacular variants. How are they used? By whom? And under what linguistic conditions? Third-wave projects would then investigate how speakers deploy the variants, examining in what social contexts they are 
used and what social meanings they produce. On the perceptual side, the question would be what social meanings, if any, the listeners connect to the variants.

As an example of how first-wave data can be a helpful point of entry for a thirdwave study, consider the overlap between two variables in West Virginia: /aj/ ungliding and quotative be like. The phonological process of /aj/ ungliding is widely distributed in the US South and has been a socially noted part of West Virginia throughout the $20^{\text {th }}$ century. The unglided variant is generally restricted to Southern areas of West Virginia and follows several phonological conditioning patterns. These include syllabic constraints for some West Virginia speakers and following phonological environments for most: In general, more sonorant, tautosyllabic following consonants favor /aj/ ungliding (Hazen 2000). The vernacular point of interest for third-wave studies is specifically /aj/ ungliding before voiceless obstruents, as in wife, pipe, or bike. This pattern is more geographically restricted and is much more highly stigmatized in West Virginia, resulting in reduced rates across the generations. Early on in this project, it became apparent that /aj/ ungliding before voiceless obstruents was an important sociolinguistic feature for speakers: For example, in one of my first interviews for WVCEA, a middle-aged woman from Charleston, WV, asked me why her father said wife [wa:f] and knife [na:f] but she said wife [wajf] and knife [najf].

Within the normal first-wave data dissection of quotative be like (Buchstaller 2013), the WVDP research team found one family with nearly categorical rates of /aj/ ungliding before voiceless obstruents. The odd speaker out in this family was a younger female speaker, Lisa, who had some college experience. Her rates of /aj/ ungliding in other environments are all high, as shown in Table 1. Yet her overall rate for /aj/ ungliding drops to $63 \%$. This drop was odd to WVDP researchers as we perceived her to be one of our premier younger speakers with /aj/ ungliding before voiceless obstruents. Following variationist methodology (Tagliamonte 2012), we checked the data to assess whether we had missed an important subcategory that would provide two different distributions whose effects were confounding the sociolinguistic analysis. Indeed, a subset of the /aj/ tokens, those within quotative be like and discourse like, were quite different than other prevoiceless tokens. 
Lisa breaks with her pattern of nearly categorical ungliding before voiceless obstruents. Within Appalachia and other US regions, quotative be like is popularly perceived to be either Californian or Mall Speak; certainly, no one perceives it to be a traditional Southern feature. In adopting a frequent use of quotative be like and discourse like, Lisa clearly has adopted the non-Appalachian, fully-glided version of /aj/ as part of the sociocultural package. As a pointed illustration, during one section of her interview, she has a string of fully-glided likes but follows directly with an unglided unlikely. It is clear that the phonological environment is not the predominant factor for her fully-glided /aj/ production.

\begin{tabular}{|c|c|c|c|c|c|}
\hline Speaker & Liquids & Nasals & Vd. obstr. & VI. obstr. & Total \\
\hline \multirow{2}{*}{ Lisa } & 5 & \multirow{2}{*}{$\begin{array}{c}55 / 55 \\
100 \%\end{array}$} & \multirow{2}{*}{$\begin{array}{c}35 / 38 \\
92 \%\end{array}$} & $\begin{array}{c}\text { 10/104 } \\
\text { (like) } \\
9.6 \%\end{array}$ & $\begin{array}{c}\text { 152/253 } \\
\text { (+like) } \\
63 \%\end{array}$ \\
\hline & $100 \%$ & & & $\begin{array}{c}47 / 51 \\
\text { (other) } \\
92 \%\end{array}$ & $\begin{array}{c}142 / 149 \\
\text { (-like) } \\
96 \%\end{array}$ \\
\hline
\end{tabular}

Table 1. /aj/ ungliding by phonological environment for one young WV speaker

In essence, there are two different distributions for Lisa's /aj/ ungliding: one for discourse like/quotative be like and a different one for all other prevoiceless /aj/ vowels. A much richer stylistic analysis is possible for Lisa within this intersection of sociallymeaningful language variation patterns. By knowing the available language variation patterns for speakers, variationists can better construct research questions on how speakers deploy them for stylistic repertoires. The possible palate of language variation patterns must first be assiduously described to ensure the best possible stylistic investigation. 


\section{Conclusion}

The progress gained from the study of language variation since the 1960s should continue in the future, and with broad enough perspectives on the goals and methods for language variation studies, it can produce benefits throughout the 21st century. Its goals and progress must, however, be regularly reassessed to provide the best possible scholarship for the two main focus areas: the sociolinguistics of society and the sociolinguistics of language (following Fasold 1987, 1990). This paper focuses on the utility of combining first-wave and third-wave variationist studies to achieve third-wave dialectology where social meaning becomes part of the dialectological focus on language variation patterns in geographic and social space.

Language variation patterns are used in a wide array of sociolinguistic investigations. As Trudgill notes (1978: 2), the term sociolinguistics applies to three different disciplines, each containing different methodologies and objectives: “... those where the objectives are purely sociological or social-scientific; those where they are partly sociological and partly linguistic; and those where the objectives are wholly linguistic". Because of the diverse methodologies available to scholars of language variation, it is of primary importance to keep in focus the object of study; language or society. Third-wave dialectology could inform both areas of scholarship.

The creation of a third-wave dialectology does not mean the end of traditional dialectological goals. Yet to create third-wave dialectological methods, a shift in focus must take place within the methods. As Eckert writes on her website about third-wave variationist analysis:

It views styles, rather than variables, as directly associated with identity categories, and explores the contributions of variables to styles. In so doing, it departs from the dialect-based approach of the first two waves, and views variables as located in layered communities. Since it takes social meaning as primary, it examines not just variables that are of prior interest to linguists (e.g. changes in progress) but any linguistic material that serves a social/stylistic purpose. And in shifting the focus from dialects to styles, it shifts the focus from speaker categories to the construction of personae. 
Dialectologia 15 (2015), 69-85.

ISSN: 2013-2247

Over its 50 year history, variationist methodology has not created a unified sociolinguistics or merged previously separate fields such as dialectology and linguistic anthropology. Linguists focused on anthropological and sociological concerns attend and publish in the venues most germane to their purposes. The same is true for dialectology. To resolve this divide, and best present ourselves to funding agencies yearning for interdisciplinary proposals and the general public, I strongly suggest that diverse scholars use teams of researchers on sociolinguistic projects to fulfill third-wave goals with the study of language variation. Those teams should include scholars focused on purely linguistic questions and those focused on purely social and anthropological questions. With the combined knowledge and goals, third-wave methods will benefit many fields involved in the study of language variation.

\section{References}

BUCHSTALLER, Isabelle (2013) Quotatives: New Trends and Sociolinguistic Implications, Malden, MA: Wiley-Blackwell.

CAMPBELL-KIBLER, Kathryn (2008) "I'Il be the judge of that: diversity in social perceptions of (ING)", Language in Society, 37.5, 637-659.

CHAMBerS, J.K. (2002a) "Studying language variation: an informal epistemology", in J.K. Chambers, P. Trudgill \& N. Schilling-Estes (eds.), The Handbook of Language Variation and Change, Oxford: Blackwell, 3-14.

CHING, Barbara \& Gerald W. CREED (eds.) (1997) Knowing Your Place: Rural Identity and Cultural Hierarchy, New York: Routledge.

COUPLAND, Nikolas (2007) Style: Language Variation and Identity, New York: Cambridge.

CoUPLAND, Nikolas (2014) "Social context, style, and identity in sociolinguistics", in Janet Holmes and Kirk Hazen (eds.), Research Methods in Sociolinguistics: A Practical Guide, Malden, MA: Wiley Blackwell, 290-303.

ECKERT, Penelope (2000) Linguistic Variation as Social Practice: The Linguistic Construction of Identity in Belten High, Oxford: Blackwell.

ECKERT, Penelope (2008) "Variation and the indexical field", Journal of Sociolinguistics, 12, 453476. 
ECKERT, Penelope (2014) "Three waves of variation study: The emergence of meaning in the study of sociolinguistic variation", Annual Review of Anthropology, 41, 87-100.

FASOLD, Ralph W. (1987) The Sociolinguistics of Society, Cambridge, MA: Blackwell.

FASOLD, Ralph W. (1990) The Sociolinguistics of Language, Cambridge, MA: Blackwell.

FRIDLAND, Valerie (2001) "The social dimension of the Southern Shift: gender, age, and class", Journal of Sociolinguistics, 5, 233-253.

GoRdon, M. J. (2006) "Interview with William Labov", Journal of English Linguistics, 34.4, 332351.

HAZEN, Kirk (2000) "A methodological suggestion on /aj/ ungilding", American Speech, 75.2, 221224.

HAZEN, Kirk (2002) "Identity and language variation in a rural community", Language, 78.2, 240257.

HAZEN, Kirk (2005) "Mergers in the mountains", English World Wide, 26.2, 199-221.

HAZEN, Kirk (2008) "(ING): a vernacular baseline for English in Appalachia”, American Speech, 83.2.

HAZEN, Kirk (2011a) "Flying high above the social radar: coronal stop deletion in modern Appalachia", Language Variation and Change, 23, 1-33.

HAZEN, Kirk (2011b) "Labov: language variation and change”, in Ruth Wodak, Barbara Johnstone, and Paul E. Kerswill (eds.), The SAGE Handbook of Sociolinguistics, New York: SAGE Publications, 24-39.

HAZEN, Kirk, Paige BUtCHER \& Ashley KING (2010) "Unvernacular Appalachia", English Today, 104.26.4, 13-22.

HAZEN, Kirk, Sarah HAMILTON \& Sarah VACOVSKY (2011) "The fall of demonstrative them: evidence from Appalachia", English World-Wide, 32:1, 74-103.

JoneS, Megan \& Sali TAgLIAMONTE (2004) “From Somerset to Samaná: Preverbal did in the voyage of English", Language Variation and Change, 16.2, 93-126.

LABOV, William (1966 [2006]) The social stratification of English in New York city, Cambridge: Cambridge University Press.

LABOV, William (2001) Principles of Linguistic Change, Volume II: Social Factors, Oxford: Blackwell.

MILROY, Lesley \& Sue MARGRAIN (1980) "Vernacular language loyalty and social network", Language in Society, 9.1, 43-70.

MOORE, Emma (2011) "Variation and identity", in Warren Maguire \& April McMahon (eds.), Analysing Variation in English, New York: Cambridge University Press, 219-236. 
Dialectologia 15 (2015), 69-85.

ISSN: 2013-2247

TAglaAmonte, Sali A. (2012) Variationist Sociolinguistics: Change, Observation, Interpretation, Malden, MA: Wiley-Blackwell.

TRUDGILL, Peter (ed.) (1978) Sociolinguistic Patterns in British English, London: Edward Arnold.

WolfRAM, Walt (1969) A Sociolinguistic Description of Detroit Negro Speech, Washington, DC: Center for Applied Linguistics.

Wolfram, Walt \& Donna Christian (1975) "Sociolinguistic variables in Appalachian Dialects", Report for National Institute of Education of the Department of Health, Education, and Welfare, NIE-G-74-0026. 